\title{
Pure, Postmitotic, Polarized Human Neurons Derived from NTera 2 Cells Provide a System for Expressing Exogenous Proteins in Terminally Differentiated Neurons
}

\author{
Samuel J. Pleasure, Constance Page, and Virginia M.-Y. Lee \\ David Mahoney Institute of Neurological Sciences, and Department of Pathology and Laboratory Medicine, University of \\ Pennsylvania School of Medicine, Philadelphia, Pennsylvania 19104-4283
}

\begin{abstract}
NTera 2/c1.D1 (NT2) cells, a human teratocarcinoma cell line, were manipulated following retinoic acid treatment to yield $>95 \%$ pure cultures of neuronal cells (NT2-N cells). The commitment of NT2-N cells to a stable neuronal phenotype is irreversible as judged by the lack of mitotic activity or phenotypic reversion over a period of 2 months in culture. Furthermore, NT2-N cells express a variety of neuronal markers including many neuronal cytoskeletal proteins, secretory markers, and surface markers. NT2-N cells resemble primary neuronal cultures from rodents morphologically and in density of process outgrowth and, like primary neurons, go on to elaborate processes that differentiate into axons and dendrites. This culture method yields sufficient highly differentiated postmitotic NT2-N cells for both biochemical and molecular biological studies. Indeed, when undifferentiated NT2 cells were stably transfected with a $\beta$-galactosidase ( $\beta$ gal) expression plasmid, $\beta$-gal expression was shown to be present in both undifferentiated NT2 and postmitotic NT2-N cells. Thus, the ability to transfect expression plasmids into undifferentiated NT2 cells will allow the introduction of normal and mutant gene products into cells that can then be induced to become stable, postmitotic human neurons. We conclude that NT2 cells and NT2-N cells represent a unique model system for studies of human neurons, and a novel vehicle for the expression of diverse gene products in terminally differentiated polarized neurons.
\end{abstract}

Mature mammalian neurons are incapable of cell division and cannot, with the exception of olfactory neurons, be generated from stem cells in the adult nervous system. Thus, continuously

\footnotetext{
Received Aug. 16, 1991; revised Dec. 3, 1991; accepted Dec. 12, 1991.

We thank all the investigators who provided the NT2 cells, antibodies, and plasmids that allowed the completion of this study. These included Dr. P. Andrews (NT2/D1, NT2/D3 and NT2/B9), Dr. L. Binder (AP14 and 1WM 3G5), Dr. A. Matus (HM1), Drs. D. Schreyer and J. H. P. Skene (9-1E10), Dr. L. Parysek (rabbit anti-peripherin), Dr. F.-C. Chiu (rabbit anti-NF-66), Dr. J. Kemshead (ERIC-1), Dr. G. Rougon (MenB), and Dr. C. Cepko (SPUD1). Dr. M. L. Schmidt was instrumental in performing the confocal microscopy. We thank Dr. John Murray for allowing us to use the confocal facility supported by NIH Grant S-10-RR05008 We also thank Dr. J. Q. Trojanowski for reading the manuscript and all the members of our laboratory who helped make this study possible. S.P. was supported by an MSTP predoctoral fellowship and the NIMH/Measey training Grant (5-T32-MH-18902) at the University of Pennsylvania. This work was supported by Grants NS-18616 and CA-36245.

Correspondence should be addressed to Dr. Virginia M.-Y. Lee, Room A009, Basement Maloney Building, HUP, 36th and Spruce Streets, Philadelphia, PA 19104-4283.
}

Copyright (C) 1992 Society for Neuroscience $0270-6474 / 92 / 121802-14 \$ 05.00 / 0$ dividing clonal cell lines with neuronal characteristics have proven to be very useful to investigators studying almost every aspect of the nervous system. Such cell lines allow the generation of large numbers of homogeneous cells and the manipulation of these cells through gene transfer to yield novel derivatives expressing foreign gene products (Lendahl and McKay, 1990). These advantages have led to the development and characterization of a variety of such cell lines, some of which have been useful for cell biological, biochemical, and molecular biological studies. The utility of these different cell lines and their ability to approximate aspects of the neuronal phenotype vary widely. To be useful, it is important that a cell line have a short doubling time so that it is possible to accumulate enough cells for biochemical studies and so that cells can be easily selected after transfection. However, the more rapidly a cell line proceeds through the cell cycle, the fewer features it has in common with neurons. The likely reason for this is that many differentiated properties of neurons are not fully articulated in vivo until they become postmitotic (Temple, 1990). Rapidly dividing neuronal cell lines usually do not express the phenotypic properties of terminally differentiated nondividing neurons. Instead, they often resemble in vivo neuroblasts or embryonic neurons. For example, many of these cell lines elaborate immature neurites with an immature cytoskeleton but lack most of the morphology and neuritic differentiation of postmitotic neurons. Such cells never go on to establish polarized neurites with the characteristics of axons or dendrites as evidenced by either distribution of cytoskeletal markers [such as MAP2 or phosphorylated neurofilament (NF) proteins] or by functional assays (see Results and Discussion for a discussion of neuritic polarity). The failure of such cell lines to establish these differentiated characteristics of neurons may be related to their inability to differentiate terminally. Further differentiation following treatment with exogenous factors of any of these cell lines (e.g., NGF treatment of $\mathrm{PC} 2$ cells) is fully reversible and therefore does not reflect a terminally differentiated state (Greene and Tischler, 1982). Naturally occurring neoplastic derivatives of many neuronal cell types of the CNS and PNS usually fall in this category (e.g., neuroblastomas, pheochromocytomas, and medulloblastomas) (He et al., 1989; Lendahl and McKay, 1990). The HCNl cell line described by Snyder and colleagues is an example of a cell line that resembles neurons closely but divides very slowly, thus limiting its use for many types of experiments (Ronnett et al., 1990).

Recently, considerable effort has been expended to immortalize specific neuronal precursors that are found transiently 
during development (for recent reviews, see Cepko, 1989; Lendahl and McKay, 1990; for specific examples, see Bartlett et al., 1988; Fredericksen et al., 1988; Birren and Anderson, 1990; Hammang et al., 1990; Ryder et al., 1990; Lo et al., 1991). This approach is valuable because these cell lines approximate characteristics of specific cell types at particular stages of development. Already, new molecules that may serve important developmental functions have been isolated using these novel cell lines (Johnson et al., 1990; Lendahl et al., 1990). However, cell lines generated using this strategy have a limited ability to undergo further ncuronal differentiation. Rather, they seem to be more useful for examining specific branch points in the emergence of neuronal lineages.

The ideal cell line for analysis of the processes of neuronal maturation and the intrinsic factors that affect the establishment of the neuronal phenotype would be one that divides rapidly so that it could be grown in large quantities and transfected to produce a stable population of cells expressing exogenous gene products. Upon induction with an agent promoting differentiation, this ideal cell line would leave the cell cycle, undergo an irreversible commitment to a neuronal phenotype, and exist in a stable postmitotic state. These cells would subsequently elaborate extensive neuritic processes and would mature to a state similar to that of primary neurons in culture. A system such as this would allow investigators to express mutant or neurotoxic proteins that would affect differentiated neuronal characteristics not found in rapidly dividing neuronal cell lines (e.g., neuritic polarity).

Embryonal carcinoma cell lines satisfy some of the above criteria. These cells, which have been derived from both murine and human embryonal tumors, consist of undifferentiated multipotential cells that will differentiate into one or several cell types when placed under certain conditions [usually including treatment with retinoic acid (RA)]. This process resembles the actual commitment to different phenotypes that are found in vivo (Kuff and Fewell, 1980; Pfeiffer et al., 1981; Darmon et al., 1982; Jones-Villeneuve et al., 1982; Paulin et al., 1982; Lang et al., 1989). The induced cell types frequently include neuronal, glial, muscle, and/or endothelial cells at various stages of differentiation (Kuff and Fewell, 1980; Pfeiffer et al., 1981; Darmon et al., 1982; Jones-Villeneuve et al., 1982; Paulin et al., 1982; Lang et al., 1989). NTera 2/D1 (NT2), a human teratocarcinoma cell line, has characteristics in common with its $\mathrm{mu}$ rine counterparts in that these cells are capable of undergoing phenotypic changes in response to RA. However, unlike most of the murine embryonal carcinoma cell lines, the only identifiable differentiated phenotype found following RA treatment of NT 2 cells is the neuron (Andrews, 1984; Andrews et al., 1984; Lee and Andrews, 1986). In all previous studies, these neurons represented a small percentage of the cells, and they coexisted with a population of unidentified large flat cells and a residual number of undifferentiated stem cells (Andrews, 1984). We reasoned that it would be desirable to obtain nearly pure neuronal cultures from RA-treated NT2 cells. To this end, we have used RA and primary culture techniques (including differential attachment to tissue culture plastic and treatment with mitotic inhibitors) to obtain highly purified populations of human neurons from NT2 cells. These neurons (NT2-N cells) express all ubiquitous neuronal markers that we examined and elaborate processes that can be identified as axons or dendrites using molecular and functional criteria. Finally, we have also shown that undifferentiated NT2 cells can be stably transfected and

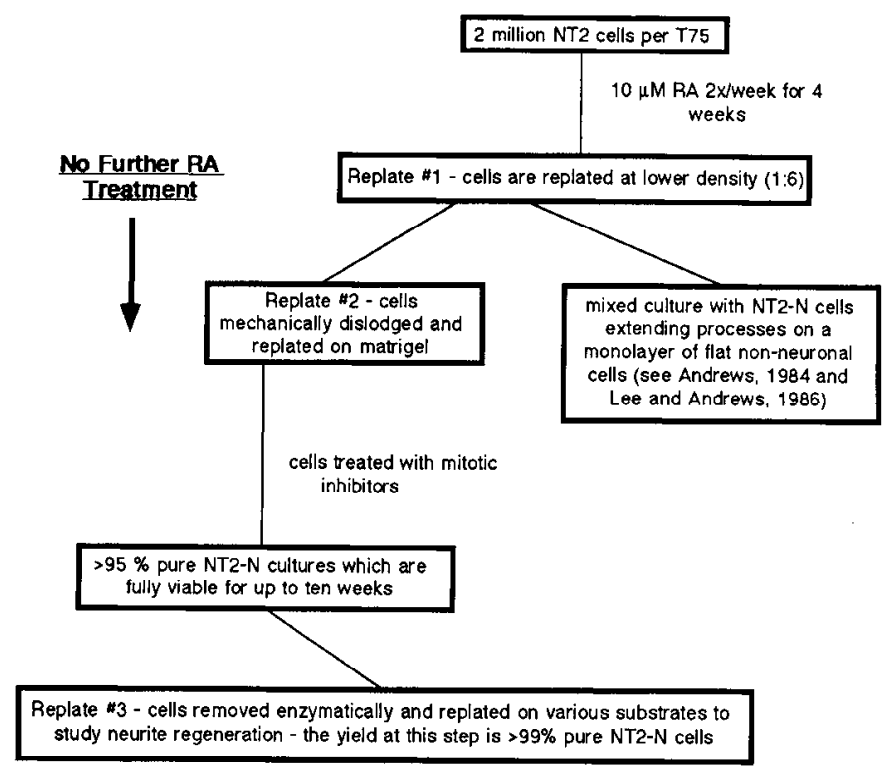

Figure 1. Schematic demonstration of the method devised for generation of purc cultures of NT2-N cells from RA-treated NT2 cells. For more details on this procedure see Materials and Methods.

that the NT2-N cells continue to express the exogenous gene product.

\section{Materials and Methods}

Cell culture. NT2 cells were maintained in Dulbecco's modified Eagle's medium (DMEM) HG including 10\% FBS and penicillin/streptomycin as previously described (Andrews, 1984). For differentiation, $2 \times 10^{6}$ cells were seeded in a $75 \mathrm{~cm}^{2}$ flask and treated with $1 \times 10^{-5} \mathrm{M}$ RA [a $1 \times 10^{-2} \mathrm{M}$ stock dissolved in dimethyl sulfoxide (DMSO) was prepared fresh monthly] twice a week for 4 weeks. Following RA treatment, the cells were replated 1:6 (Replate \#1, Fig. 1). On the following 2 days, cells were mechanically dislodged, that is, culture flasks were struck 10 times on each side and the floating cells were washed with $5 \mathrm{ml}$ of medium and replated again (Replate \#2, Fig. 1) on Matrigel (Collaborative Research) diluted 1:20 (for coverslips) or 1:60 (for dishes) following the manufacturer's instructions (the dilutions used for the Matrigel varied somewhat from lot to lot). Cells were secded at a density of $0.2 \times 10^{6}$ cells per $12 \mathrm{~mm}$ coverslip or $7.5 \times 10^{6}$ cells per $100 \mathrm{~mm}$ dish in DMEM HG with $10 \%$ fetal bovine serum (FBS) and penicillin/ streptomycin supplemented with $1 \mu \mathrm{M}$ cytosine arabinoside, $10 \mu \mathrm{M}$ fluorodeoxyuridine, and $10 \mu \mathrm{M}$ uridine. Cytosine arabinoside was continued for the first week of culture, and fluorodeoxyuridine and uridine, for the first 4 weeks. For neurite regeneration experiments, 1-3-week-old cultures were enzymatically removed with $0.025 \%$ dispase or $0.025 \%$ trypsin and replated (Replate \#3, Fig. 1) on Matrigel, poly-D-lysine (10 $\mu \mathrm{g} / \mathrm{ml})$, or poly-D-lysine $(10 \mu \mathrm{g} / \mathrm{ml})$ plus laminin $(10 \mu \mathrm{g} / \mathrm{ml})$. Following replate 3 , it is possible to freeze the fully differentiated pure cultures of neurons in $95 \%$ FBS with $5 \%$ DMSO and to retrieve them at a later date. Matrigel is a basement membrane extract containing collagen, laminin, and nidogen (Kleinman et al., 1986). This method as outlined in Figure 1 and described in detail here was applicd to three different NTera 2 subclones (NT2/D1, NT2/D3, and NT2/B9) with similar results. All results presented here were obtained from NT2/DI. During the course of these experiments, we found that NT2 cells prefer OptiMEM (GIBCO) with 5\% FBS and began using this medium for maintaining the undifferentiated NT2 cells.

BrDU labeling. Undifferentiated NT2 cells and differentiated NT2-N cells were grown free of mitotic inhibitors for $4 \mathrm{~d}$ and then labeled with $3 \mathrm{mg} / \mathrm{ml}$ bromodeoxyuridine (BrDU) for $3 \mathrm{hr}$ (or up to $20 \mathrm{hr}$ in some cases). The cells were then washed, fixed, and processed for indirect immunofluorescence as described below using BU-1, a monoclonal antibody $(\mathrm{mAb})$ that recognizes $\mathrm{BrDU}$ incorporated DNA without denaturation. 
Indirect immunofluorescence. Cells were washed with Hank's buffered salt solution and fixed with $70 \%$ ethanol containing $0.15 \mathrm{M} \mathrm{NaCl}$ for 10 min at room temperature. The cells were incubated with primary antibodies for $1 \mathrm{hr}$ at room temperature, washed four times with PBS for $1 \mathrm{hr}$, incubated for $1 \mathrm{hr}$ with secondary antibodies [donkey anti-mouse IgG coupled to tetramethylrhodamine isothiocyanate donkey anti-rat coupled to fluorescein isothiocyanate (FITC), and donkey anti-rabbit coupled to FITC; Jackson Immunoresearch], and finally washed four times in PBS for $1 \mathrm{hr}$ before mounting in Aquamount (Lerner Labs). For confocal microscopy, the procedure was essentially the same except that Texas red-conjugated secondary antibody was used instead of rhodamine and the coverslips were mounted using 5\% DABCO to prevent bleaching. The coverslips were then examined using a krypton laser on a Bio-Rad MRC-600 laser scanning confocal microscope

PAP immunocytochemistry. Peroxidase-antiperoxidase (PAP) immunocytochemistry was performed to visualize low levels of fetal tau because of the great sensitivity of this technique when compared to indirect immunofluorescence. The coverslips were fixed as above and blocked for 30 min with 0.1 M Tris, pH 7.0 , including $2 \%$ calf serum and $0.25 \%$ cold water fish gelatin. Following this, the coverslips were processed as described previously in our laboratory for PAP immunocytochemistry (Carden et al., 1987).

Immunochemistry. Microtubule-associated protein (MAP)-enriched cytoskeletal samples were prepared by extracting the cells at room temperature for $15 \mathrm{~min}$ with $0.1 \mathrm{M}$ morpholine ethanesulfonic acid, $\mathrm{pH} 6.8$, containing $0.5 \mathrm{mM} \mathrm{MgSO}_{4}, 1 \mathrm{~mm}$ EGTA, $2 \mathrm{~mm}$ dithiothreitol, $2 \mathrm{~mm}$ GTP, $20 \mu \mathrm{M}$ Taxol, $1 \%$ Triton $X-100$, and a cocktail of protease inhibitors. The pellets were recovered by centrifugation at $30,000 \mathrm{rpm}$ in a TL100 ultracentrifuge for $30 \mathrm{~min}$ and solubilized in sample buffer without dye, and the protein concentrations of the samples were determined using a Coomassie blue dye binding assay (Pierce). These samples were run on SDS-PAGE gels and then electroblotted to nitrocellulose membranes for probing with antibodies using methods described previously in our laboratory (Lee et al., 1987).

${ }^{3} \mathrm{H}$-uridine labeling of NT2-N cells. Dishes $(60 \mathrm{~mm})$ of NT2-N cells were incubated with $50 \mu \mathrm{Ci}$ of $5,6-^{3} \mathrm{H}$-uridine $(1.70 \mathrm{TBq} / \mathrm{mmol})$ for $16-$ $24 \mathrm{hr}$. These dishes were then washed with PBS containing $10 \mu \mathrm{M}$ unlabeled uridine, fixed with Bouin's fixative, and then coated with NTB-2 emulsion diluted 1:1 with water, dried overnight, and stored at $4^{\circ} \mathrm{C}$ for $4 \mathrm{~d}$. The dishes were developed for $1 \mathrm{~min}$ in Kodak D19 and fixed in Kodak Rapid-Fix.

Transfection and staining for $\beta$-galactosidase. Undifferentiated NT2 cells were transfected with $100 \mu \mathrm{g}$ SPUD1 and $10 \mu \mathrm{g}$ of pSV2neo by lipofection using Lipofectin (Bethesda Research Laboratories). After 2 d in complete medium, the transfectants were selected with $200 \mu \mathrm{g} / \mathrm{ml}$ G418 (GIBCO) for $7 \mathrm{~d}$. Cells were stained for $\beta$-galactosidase $(\beta$-gal) activity with $1 \mathrm{mg} / \mathrm{ml} \mathrm{X}$-gal, $5 \mathrm{~mm}$ potassium ferrocyanide, $5 \mathrm{~mm}$ potassium ferricyanide, $2 \mathrm{mM} \mathrm{MgCl}$, in PBS after fixation in $2 \%$ paraformaldehyde, $0.2 \%$ glutaraldehyde in phosphate-buffered saline, $\mathrm{pH} 7.4$. $\beta$-Gal-positive cultures were subcloned twice, and the subclones were used for further studies. SPUD1 (kindly provided by Dr. C. Cepko, Harvard University) is a $\beta$-galactosidase expression vector that utilizes the SV40 promoter and has Moloney murine leukemia virus long terminal repeats upstream and downstream (Walsh and Cepko, 1988). The cells were photographed using Hoffman modulation contrast to allow the simultaneous visualization of the blue reaction product and the processes.

\section{Results and Discussion}

Nearly pure cultures of NT2-N cells generated from RA-treated NT2 cells

The generation of highly purified cultures of NT2-N cells from RA-treated NT2 cells is schematically outlined in Figure 1. When undifferentiated NT2 cells were initially plated, they appeared as phase-dark cells with a granular appearance (Fig. $2 A$ ). Following 4 weeks of RA treatment, the cells formed an extremely dense multilayered culture in which it was impossible to visualize any structures by phase-contrast microscopy (data not shown). These cultures were then dispersed and replated at a lower density to release the NT2-N cells buried in the midst of the many layers of cells. Following this treatment, the NT2-N cells were seen as small phase-bright cells above a layer of flat cells (replate 1; Fig. $2 B$ ). The derivation, differentiation para- digm, and early morphological appearance of NT2 cells following treatment with RA to this point (i.e., replate 1) were examined in detail previously (Andrews, 1984; Andrews et al., 1984). In accordance with these reports, approximately $5 \%$ of the cells after replate 1 are neurons as judged by the presence of neuron-specific markers. To enrich further for these neurons, we took advantage of the fact that the small phase-bright NT2-N cells were loosely attached to the layer of flat cells after replate 1 cultures and could be mechanically dislodged and enriched. This treatment (replate 2), which is similar to the methods traditionally used to enrich for neurons in primary cultures, yielded a culture consisting primarily of small, rounded phase-bright cells, some of which had short processes reminiscent of human neuroblastoma cell lines (Fig. 2C). This step led to an approximately fourfold enrichment of the neuronal cells as assayed by the measurement of neuronal-specific enzymes (S. R. Kleppner, S. J. Pleasure, and V. M.-Y. Lee, unpublished observations). These cultures also contained some flat cells, which resembled undifferentiated NT2 cells, that when allowed to grow unchecked, gradually formed a monolayer with the small, phasebright cells sitting on top. After replate 2, the phase-bright NT2-N cells grew numerous processes and formed large cellular aggregates within 2 weeks, and were viable for up to 10 months without ever showing any phenotypic reversion as determined by the continuous presence of neuron-specific markers (data not shown). However, these cultures were not significantly better than mixed cultures derived from replate 1 because of the presence of the contaminating monolayer of flat cells (Andrews, 1984; Lee and Andrews, 1986). To eliminate these dividing flat cells, the cultures were treated with a combination of mitotic inhibitors following replate 2 (see Materials and Methods). This treatment had no effect on the NT2-N cells, but it completely suppressed the growth of the flat cells. Hence, nearly all of the flat cells were eliminated, leaving behind a very small number of mitotically poisoned cells with extensive cytoplasm. By 2 weeks of treatment, about $95 \%$ of the cells were differentiated neurons, that is, NT2-N cells. We confirmed this observation, obtained roughly from phase-contrast microscopy, by double staining cultures of cells using antibodies specific for either the undifferentiated NT2 cells (Cam5.2, which reacts with keratins 8 and 18) or the NT2-N cells [rabbit anti-low molecular weight NF (NF-L), which reacts exclusively with the NF-L protein]. Thesc experiments showed NT2-N cells stained with the NF-L antiserum and only very occasional flat cells with extensive cytoplasm stained with Cam5.2 (data not shown). When cultured on Matrigel, which served as a better substrate for these cells than poly-D-lysine or poly-D-lysine and laminin, these nearly pure cultures of NT2-N cells were viable for about 10 weeks.

When these cultures were examined using phase-contrast microscopy at various times (Fig. $2 D, E$ ), progressive development of extensive neuritic networks covering the entire culture dish was observed. Fine, untapering long processes, similar to the axonal processes described in primary neuronal cultures, were also evident. As shown in Figure $2 F$, single cells in these cultures elaborated processes that were thick at the base and tapered progressively from the cell body (arrowheads in Fig. $2 F$ ). Additionally, thin untapering processes arose from these cells (arrows in Fig. $2 F$ ). These two morphologically distinct types of processes rescmblcd the dendrites and axons, respectively, of primary cultures of CNS and PNS neurons. The identity of these two classes of processes as axons and dendrites was borne out by molecular markers of axons and dendrites they expressed (see below). During this period of extensive process outgrowth, 

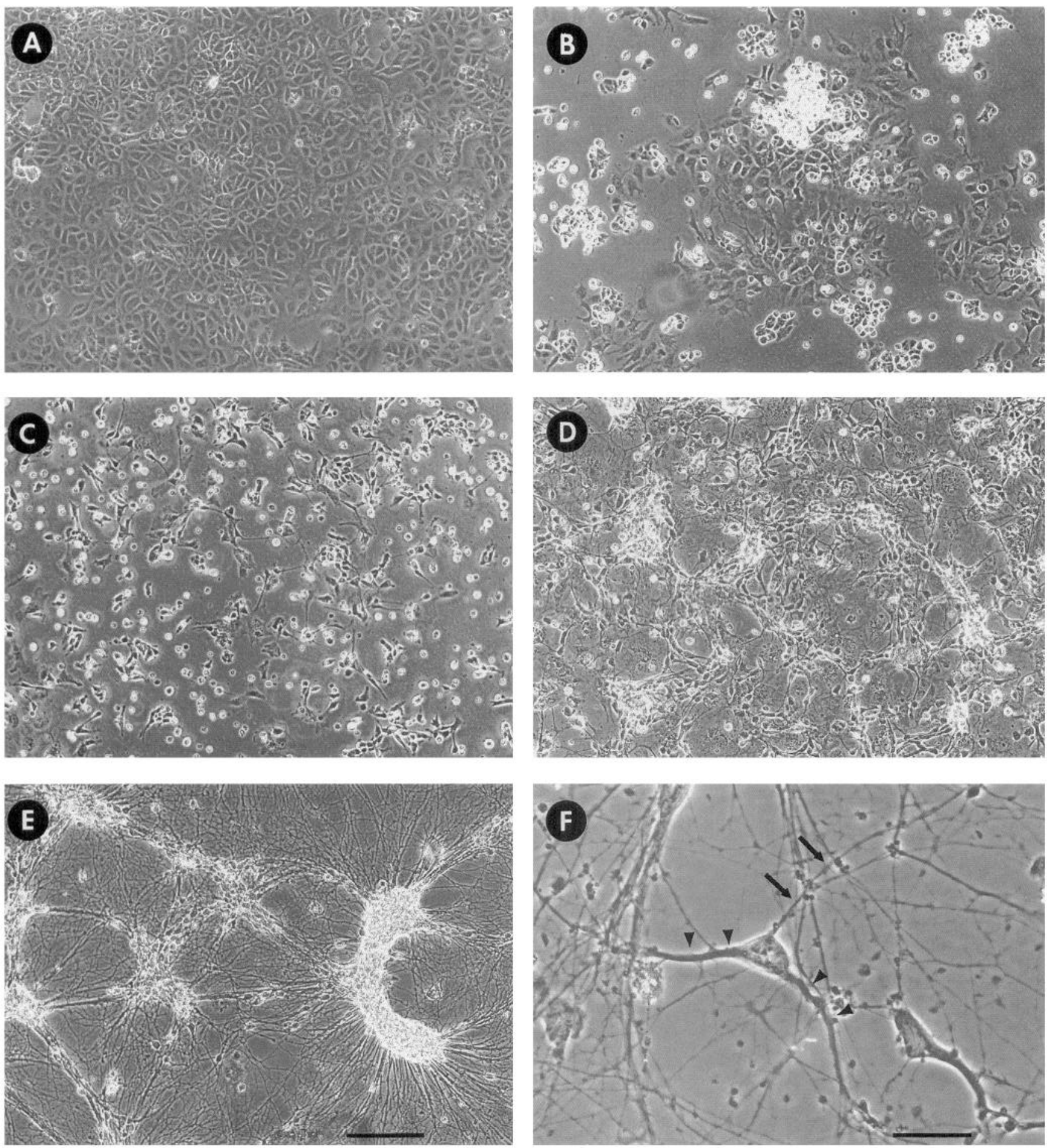

Figure 2. Phase-contrast photomicrographs showing the morphologic changes that occur during the course of the procedure outlined in Figure 1 . $A$, untreated NT2 cells; $B$, NT2 cells following replate 1 (note the round, phase-bright cells in clumps sitting above the adherent cells below); $C$, 1 $\mathrm{d}$ following replate 2 (note that many cells have begun to elaborate rudimentary processes similar to a number of human neuroblastoma cell lines); $D, 7 \mathrm{~d}$ following replate 2 (the non-neuronal cells have begun to die off, and the cultures are now dominated by neuronlike NT2-N cells); $E$, $30 \mathrm{~d}$ following replate 2 (note that most cells exhibit the morphology of neurons and have migrated into large aggregates and that extensive process outgrowth has occurred); $F$, high-power photomicrograph of NT2-N cells showing the typical neuronal morphology of these cells. The arrows point to the long, thin untapering process resembling an axon emanating from a cell in Figure $2 F$. The arrowheads point to the two major processes that resemble dendrites. Scale bars: $E$ (for $A-E$ ), $200 \mu \mathrm{m} ; F, 30 \mu \mathrm{m}$. 

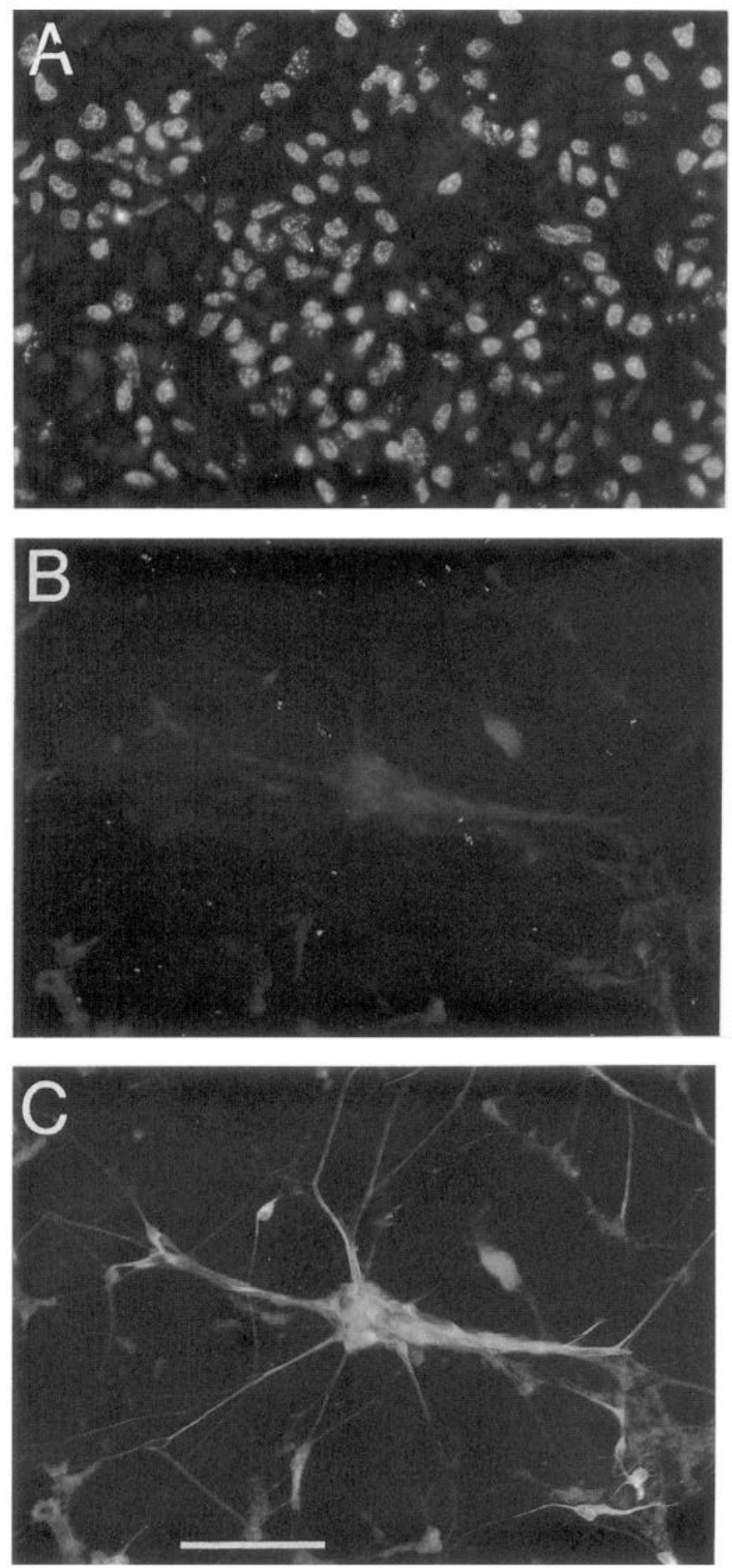

Figure 3. BrDU labeling of NT2 and NT2-N cells. $A$, Undifferentiated NT2 cells labeled with BrDU and stained with BU-1. $B$, NT2-N cells labeled with BrDU and stained with BU-1. $C$, The same field as $B$ labeled with an anti-NF-L antiserum. Scale bar, $200 \mu \mathrm{m}$.

the NT2-N cells displayed growth cones typical of primary cultures of neurons from various regions of the nervous system. Another consistent feature of pure NT2-N cells was their motility. Initially, NT2-N cells were evenly dispersed over the entire surface of the culture dish (Fig. 2C), but over time they migrated together to form cellular aggregates with large interconnecting fascicles of axons (Fig. 2D). If the cells were plated on poly-D-lysine either alone or with laminin, they formed even larger aggregates that resembled explanted ganglia (data not shown).

We examined the reproducibility of this new method to generate large numbers of NT2-N cells by recording the number of cells harvested from replate 2 in a series of experiments. Over a number of trials $(n=9)$, beginning with a T75 culture flask seeded with $2 \times 10^{6} \mathrm{NT} 2$ cells, treated with $1 \times 10^{-5} \mathrm{M}$ RA for 4 weeks (see Materials and Methods), and then taken through replates 1 and 2, we recovered an average of $48.9 \times 10^{6}$ cells $\left(\mathrm{SEM}=3.3 \times 10^{6} ; n=9\right)$. Despite limitations in available techniques to estimate the number of NT2-N cells, our quantitative data indicate that approximately $20 \%$ of the cells recovered after replate 2 were NT2-N cells. Thus, the average yield per T75 flask is about $10 \times 10^{6}$ cells.

\section{NT2- $N$ cells are postmitotic}

In order to demonstrate that NT2-N cells were incapable of cell division, cultures of both NT2-N cells and undifferentiated NT2 cells were incubated with BrDU and labeled nuclei were visualized by indirect immunofluorescence using an $\mathrm{mAb}$ to $\mathrm{BrDU}$ incorporated into DNA. More than $50 \%$ of the nuclei from undifferentiated cells were immunostained by the mAb after 3 hr of BrDU labeling (Fig. 3A). In contrast, there were no labeled NT2-N nuclei in pure replate 2 cultures (Fig. $3 B$ ), nor was there labeling after $20 \mathrm{hr}$ exposure (data not shown). The same cells were also stained with an antiserum against NF-L to show that NT2-N cells are present in the field (Fig. 3C). Furthermore, visual inspection of NT2-N cells either in pure cultures after withdrawal from mitotic inhibitors, or in mixed cultures, never detected an increase in the number of neuronal cells. In fact, we have followed single clumps of NT2-N cells over 3 months and we have not detected an increase in cell number despite the absence of mitotic inhibitors and the presence of $10 \%$ FBS in the medium for the entire culture period. Taken together, these data argue strongly that NT2-N cells are postmitotic.

\section{$N T 2-N$ cells express many neuronal markers}

Previous studies estimated that NT2-N cells in the previously described culture system (i.e., cultures derived from replate 1; see Fig. 1) made up a minor component of the total cell population (Andrews, 1984; Lee and Andrews, 1986). These cells were shown previously to express NF proteins (Andrews, 1984; Lee and Andrews, 1986), the antigen recognized by $A_{2} B_{5}$ (an $\mathrm{mAb}$ recognizing a cell surface glycolipid characteristic of neurons and some glial cells), and to possess TTX-sensitive $\mathrm{Na}^{+}$ channels (Rendt et al., 1989). We have confirmed and extended many of these findings using pure cultures of NT2-N cells in studies designed to examine the expression of several markers typical of neurons in vivo and in vitro (Table 1). In addition to the well-known NF triplet proteins (Table 1; Figs. $3 C, 4 A, 5$; Andrews, 1984; Lee and Andrews, 1986), NT2-N cells expressed $66 \mathrm{kDa}$ NF protein (NF-66; also known as $\alpha$-internexin; Fig. $4 B$ ) but not peripherin (Table 1), the two more recently described members of the neuronal intermediate filament family. NT2-N cells, therefore, may resemble CNS neurons because NF-66 is abundant only in the CNS, and peripherin is found in virtually all PNS neurons (Parysek and Goldman, 1988; Brody et al., 1989; Chiu et al., 1989; Escurat et al., 1990; Gorham et al., 1990; Kaplan et al., 1990). NT2-N cells also expressed several neuronal MAPs, that is, MAP1A, MAP1B, MAP2, and tau (Table 1, Fig. $4 C, D, F$ ). Furthermore, NT2-N cells lack a newly 
Table 1. Markers of the neuronal phenotype of NT2-N cells

\begin{tabular}{|c|c|c|c|}
\hline Protein & Antibody & Result & Reference or source of antibody \\
\hline NF-L & Rabbit anti-NF-L & + & Trojanowski et al., 1989a \\
\hline NF-M & RMO254 & + & Lee et al., 1987 \\
\hline NF-H & RMO24 & + & Lee et al., 1987 \\
\hline NF-66 & Rabbit anti-NF-66 & + & Chiu et al., 1989 \\
\hline Vimentin & Rabbit anti-vimentin & $+a$ & Pleasure et al., 1990 \\
\hline Peripherin & Rabbit anti-peripherin & - & Parysek et al., 1988 \\
\hline GFAP & $2.2 \mathrm{~B} 10$ & - & Lee et al., 1984 \\
\hline Keratins 8 and 18 & Cam5.2 & - & Becton Dickinson \\
\hline MAPIA & HM 1 & + & Huber and Matus, 1984 \\
\hline MAPIB & IWM 3G5 & + & L. Binder, unpublished observations \\
\hline MAP2 & AP14 & + & Geisert et al., 1990 \\
\hline Tau & $\mathrm{T} 14$ & + & Trojanowski et al., $1989 \mathrm{~b}$ \\
\hline Synaptophysin & SY -38 & + & Boehringer Mannheim \\
\hline Chromogranin & LKH110 & + & Boehringer Mannheim \\
\hline GAP-43 & $9-1 \mathrm{E} 10$ & + & Goslin et al., 1990 \\
\hline Ganglioside $\mathrm{G}_{\mathrm{T} 3}$ & $\mathrm{~A}_{2} \mathrm{~B}_{5}$ & + & Dubois et al., 1990 \\
\hline NCAM & ERIC-1 & + & Patel et al., 1990 \\
\hline PSA-NCAM & MenB & + & Theodosis et al., 1991 \\
\hline Ll (NILE) & Guinea pig anti-NILE & - & Lee et al., 1981 \\
\hline
\end{tabular}

This table presents the results obtained when NT2-N cells were examined with a number of antibodies specific for the proteins shown in the first column. $(+)$ indicates that the antibody stained and/or blotted the relevant protein in NT2-N cells. (-) Indicates that the relevant antibody does not stain NT2-N cells. GFAP, glial fibrillary acidic protein.

${ }^{a}$ Rabbit anti-vimentin is positive on Western blots of NT2-N cell extracts but does not stain these cells by indirect immunofluorescencc. This antiserum is capable of staining vimentin in other cclls (including the undifferentiated NT2 cells); therefore, it seems likely that the large amount of NF proteins assembled in the same filaments with the vimentin masks the reactivity of vimentin in NT2-N cells.

cloned high molecular weight $(110 \mathrm{kDa})$ tau isoform that is expressed in most, if not all, immature and mature PNS neurons but not in CNS neurons (Georgieff et al., 1991; M. Goedert, personal communication). Neuronal membrane or membraneassociated antigens were also expressed by NT2-N cells. These included the antigen recognized by $\mathrm{A}_{2} \mathrm{~B}_{5}$ (Fig. $4 E$ ), NCAM [another cell surface molecule frequently expressed by neurons and neuronal neoplasms (Patel et al., 1990; Table 1)], and GAP43 [a growth-associated protein concentrated in growth cones (Benowitz and Routtenberg, 1987; Table 1)]. Much of the NCAM expressed by NT2-N cells is polysialated and thus is likely to resemble NCAM found in developing systems (Theodosis et al., 1991). We also found that NT2-N cells expressed markers of secretory activity typical of neurons and neuroendocrine cells (e.g., synaptophysin and chromogranin; Table 1). Synaptophysin is a marker for small transparent synaptic vesicles that store and release classical neurotransmitters, and chromogranin is a marker for larger dense-cored vesicles that are involved in neuropeptide and catecholamine biosynthesis (Wiedenmann and Huttner, 1989).

Immunochemical studies were conducted to confirm the expression of several of the markers mentioncd above (Fig. 5) as well as to demonstrate the feasibility of using NT2-N cells for biochemical studies. I Jsing gel replicas of NT2-N cytoskeletal extracts (see Materials and Methods), we confirmed that MAP1B, MAP2, tau, NF-L, NF-M, and NF-66 were indeed present in these cells. Coomassie blue-stained gels (data not shown), together with the immunoblot in Figure 5, suggest that MAP2 in NT2-N cells comigrates with the lower of the two isoforms of bovine MAP2. Because of its sensitivity to proteolysis, MAP2 has never been identified biochemically from human tissue. Nevertheless, we hypothesize that the MAP2 from NT2-N cells is likely to be MAP2b, a less phosphorylated form of MAP2, which predominates during development and corresponds to the more rapidly migrating of the two MAP2 polypeptides in the bovine MAP2 preparations (Riederer and Matus, 1985; Matus, 1988). Figure 5 also shows that the tau found in NT2-N cells corresponds to the fetal forms rather than the adult or high molecular weight forms of tau. Fetal tau is translated from differentially spliced forms of tau mRNA that are predominant during embryonic life (Mareck et al., 1980; Francon et al., 1982; Lee et al., 1988; Matus, 1988). MAP1B (also known as MAP5) is also an embryonic MAP that persists into adulthood but at greatly reduced levels (Calvert and Anderton, 1985; Riederer et al., 1986; Schoenfeld et al., 1989; Tucker et al., 1989; Garner et al., 1990; Tohyama et al., 1991). NT2-N cells express low levels of MAP1A and high molecular weight NF protein (NF$\mathrm{H}$ ) (data not shown and Table I), two proteins that are upregulated in their expression during development but that only achieve their highest levels in adult nervous systems including that of humans (Julien et al., 1986; Carden et al., 1987; Foster et al., 1987; Schoenfeld et al., 1989; Garner et al., 1990; Tohyama et al., 1991). This finding, together with the expression of three embryonic MAPs, polysialatcd NCAM, and NF-66, implies that the cytoskeleton of NT2-N cells resembles that of embryonic CNS neurons.

\section{NT2- $N$ cells have axons and functional dendrites}

Among the most identifiable and highly differentiated features of neurons is their highly polarized phenotype. Neurons typically have a single axon and multiple dendrites that can be distinguished by their morphology, by the organelles they contain, and by several differentially distributed molecular markers (Black and Baas, 1989; Sargent, 1989). For example, the cell 

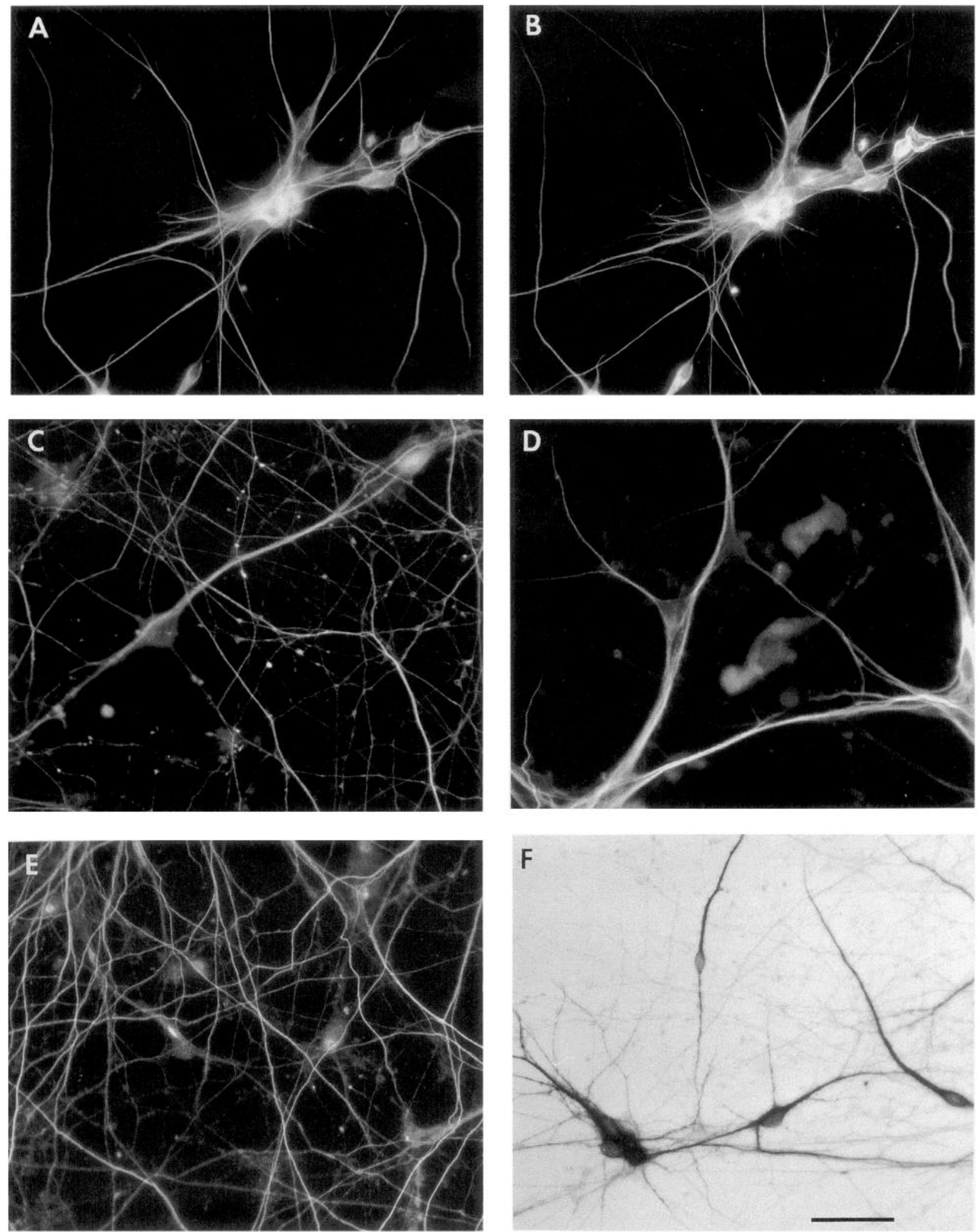

Figure 4. Immunocytochemistry documents the expression of neuronal markers in NT2-N cells. $A$ and $B$, double labeling with RMO254, a mouse anti-NF-M mAb, and anti-NF-66, a rabbit antiserum raised against NF-66; $C$, 1WM 3G5, a mouse anti-MAP1b mAb; $D$, AP14, a mouse antiMAP2 $\mathrm{mAb} ; E, \mathrm{~A}_{2} \mathrm{~B}_{5}$, a mouse mAb specific for a ganglioside found on many neurons; $F$, T14, a mouse anti-tau mAb. Scale bar, $30 \mu \mathrm{m}$. 

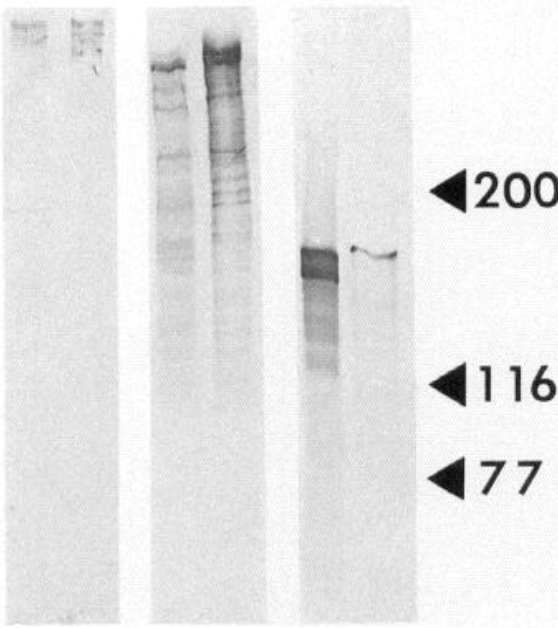

12

34

56

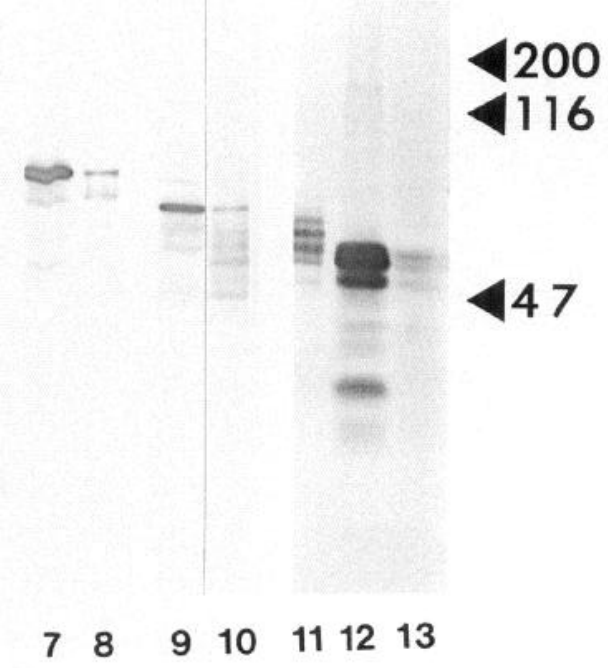

Figure 5. Immunoblots analysis of the expression of cytoskeletal markers in NT2-N cells. Lanes $1-6$ are from $6 \%$ SDS-PAGE gels, and lanes 7-13 are from $10 \%$ SDS-PAGE gels. $l, 20 \mu \mathrm{g}$ of cytoskeletal extract from NT2-N cells; 2, bovine MAPs blotted with IWM $3 \mathrm{G} 5$, an anti-MAPIb mAb; 3, $20 \mu \mathrm{g}$ of cytoskeletal extract; 4 , bovine MAP2 blotted with AP14, an anti-MAP2 mAb; $5,10 \mu \mathrm{g}$ of cytoskeletal extract; 6 , human nerve root intermediate filament preparation blotted with $\mathrm{RMO} 254$, an anti-NF-M mAb; 7, $20 \mu \mathrm{g}$ of cytoskeletal extract; 8 , human nerve root intermediate filament preparation blotted with anti-NF-L, an antiserum raised to a human NF-L; $9,20 \mu \mathrm{g}$ of cytoskeletal extract; 10, bovine NF-66 blotted with anti-NF-66, an antiserum raised to rat NF-66; 11 , purified adult human tau; 12 , purified human fetal tau; 13 , $60 \mu \mathrm{g}$ of cytoskeletal extract blotted with $\mathrm{T} 14$, an anti-tau mAb. Molecular mass markers are in $\mathrm{kDa}$ as indicated. body and dendrites (somatodendritic domain) have ribosomes (and thus contain RNA) while axons (axonal domain) lack ribosomes (Banker and Cowan, 1979; Steward and Levy, 1982; Davis et al., 1987, 1990; Black and Baas, 1989; Sargent, 1989). Further, the microtubules in dendrites are oriented in both directions while those in axons have their positive end oriented distally (Burton and Paige, 1981; Heidemann et al., 1981; Baas et al., 1988, 1989). Finally, axons are rich in highly phosphorylated NF proteins and tau while cell bodies and dendrites have primarily hypophosphorylated variants of NF proteins (Peng et al., 1986) and MAP2 (Matus et al., 1981; Caceres et al., 1984; Peng et al., 1986; Dotti et al., 1987; Kosik and Finch, 1987). These differences are all likely to contribute to the distinct functions of dendrites as primarily postsynaptic processes and of axons as projecting presynaptic processes.

Because of the highly polarized morphology of NT2-N cells after 3-4 weeks in culture, we decided to examine whether the processes of NT2-N cells can be differentiated into axons and dendrites. Indeed, when we examined the distribution of phosphoisoforms of NF-M in NT2-N cells using confocal microscopy, we found that highly phosphorylated NF-M is found preferentially in the long, thin processes emanating from NT2-N cells while hypophosphorylated NF-M is found in the cell body and short, tapering processes (Fig. $6 A, B$ ). MAP2 is also localized exclusively in the cell soma and the short processes of NT2-N cells (Fig. 6C). The nonoverlapping distribution of these proteins is very clearly seen using the computer-generated superimposed pseudocolor images in Figure 6. The somatodendritic domains of the cells were stained (in red) by the mAbs against hypophosphorylated NF-M (RMdO20; Fig. $6 A, B)$ and MAP2 (AP14; Fig. 6C) but were unstained by $\mathrm{HO} 14$ (in green), an $\mathrm{mAb}$ specific for highly phosphorylated NF-M. Conversely, the axons passing through the fields shown in Figure 6 were only stained with $\mathrm{HO} 14$.

We also examined a more directly functional feature of dendrites to determine if NT2-N cells possessed functioning dendrites. As mentioned above, dendrites accumulate ribosomes so that they can respond rapidly to synaptic signals with changes in protein synthesis. This makes it possible to use ${ }^{3} \mathrm{H}$-uridine to label dendritic processes in neurons in culture (Banker and Cowan, 1979; Davis et al., 1987, 1990). We used this technique to label NT2-N cells and found that, following emulsion autoradiography, processes resembling dendrites are indeed darkly labeled with silver grains while the long-projecting, untapered processes remain unlabeled (Fig. 7). We conclude that NT2-N cells do indeed possess identifiable dendrites and axons as determined by several criteria. One interesting point is the localization of tau throughout the cell body, dendrites, and axons in NT2-N cells (Fig. 4F). This is distinct from the finding in sympathetic and cerebral neurons in culture (Peng et al., 1986; Kosik and Finch, 1987) but is quite similar to what has been observed in hippocampal neurons (Dotti et al., 1987). Thus, while it is clear that tau is necessary for axonal elongation in some neurons in culture (Caceres and Kosik, 1990; Caceres et al., 1991) (perhaps only in those where tau is restricted to axons), additional studies will be necessary to determine the functional role of tau in axonal growth in cells (i.e., NT2-N cells and hippocampal neurons) that do not restrict its distribution to axons. This peculiarity of NT2-N cells and hippocampal neurons may be related to their expression of fetal tau rather than adult tau (see above and Dotti et al., 1987).

\section{Regeneration of neurites following replate 3 occurs rapidly and is dependent on the culture substrate}

Since NT2-N cells may be a model for immature CNS neurons, studies were conducted to assess their plasticity. When pure cultures of NT2-N cells (cells grown for 1-3 weeks following replate 2) were enzymatically detached and replated again (replate 3 ), they rapidly reextended neurites. These processes continued to elongate until a dense network of neurites was formed by 1 week following replating (Fig. $8 A$ ). Interestingly, the rapid elaboration of neurites and the eventual formation of the network of processes was highly dependent on the substratum used. For example, rapid outgrowth occurred on cells grown on polyD-lysine plus laminin or Matrigel substrates but not on poly-Dlysine alone. Figure $8 B$ illustrates cell clumps grown on poly-Dlysine alone. Even after $7 \mathrm{~d}$, these cells had very short processes that ended in flat broad growth cones. By $20 \mathrm{hr}$, the NT2-N 

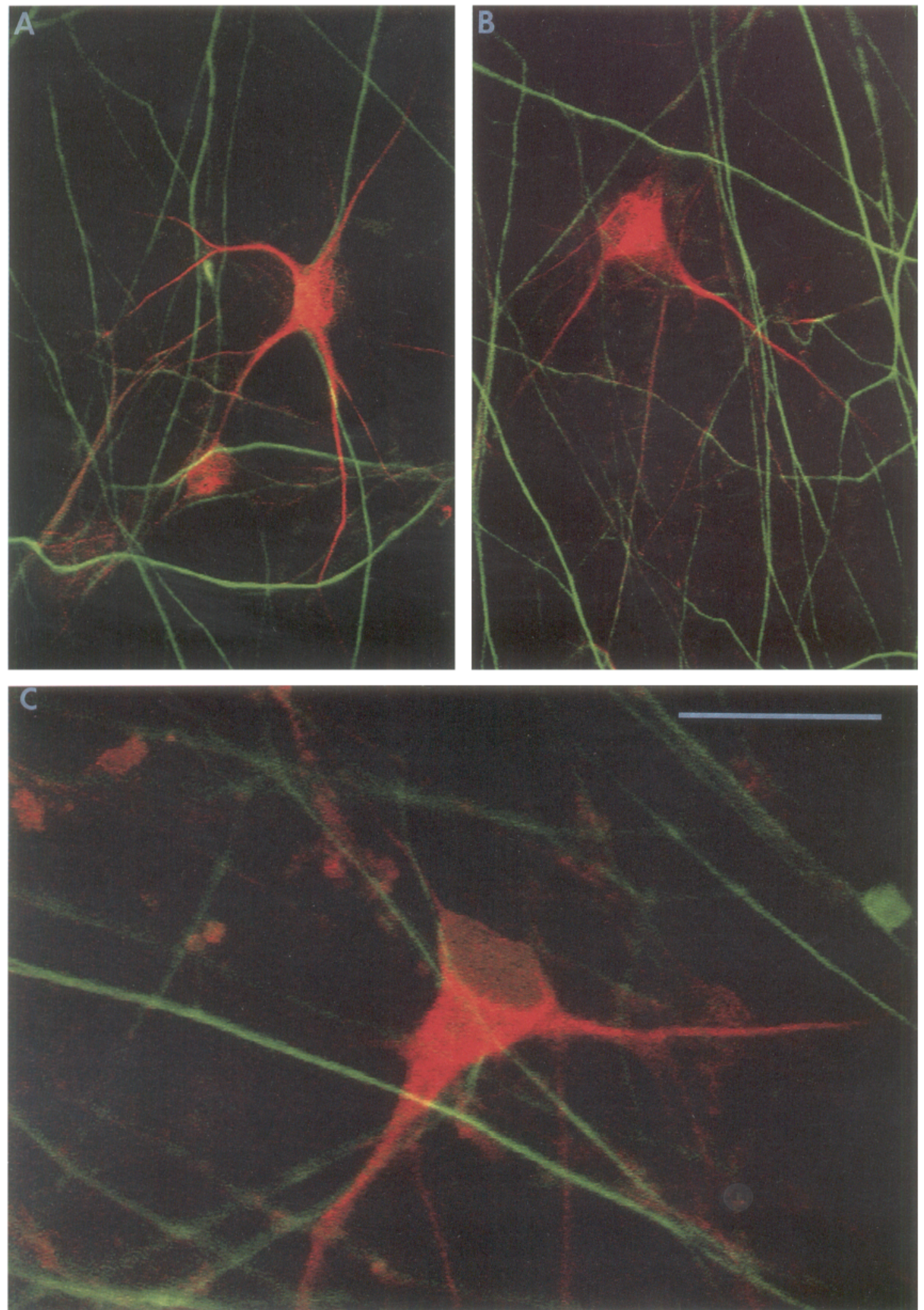

Figure 6. Confocal microscopy of NT2-N cells stained with markers for axons and dendrites. $A$ and $B$ show microscopic fields stained with HO14 (green) and $\mathrm{RMdO} 20$ (red). HO14 is a rat mAb specific for the highly phoshorylated forms of NF-M, while RMdO20 is a mouse mAb specific for the poorly phosphorylated forms of NF-M. $C$ shows a high-power field of cells stained with HO14 and AP14, a mouse mAb specific for MAP2. These images were generated by collecting separate data for each channel and then merging them and imparting them with computer-generated pseudocolor. Scale bar: $50 \mu \mathrm{m}$ for $A$ and $B ; 25 \mu \mathrm{m}$ for $C$. 

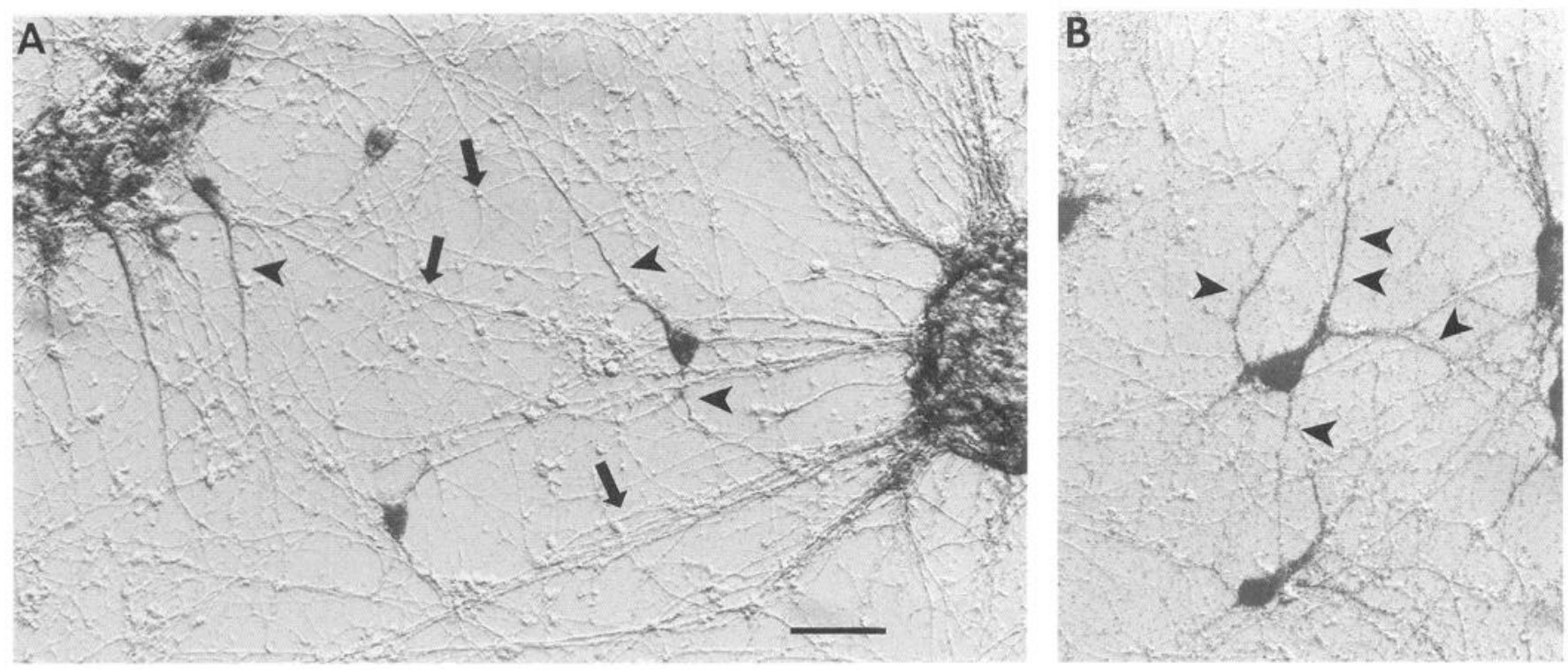

Figure 7. ${ }^{3} \mathrm{H}$-uridine labeling of NT2-N cell cultures 5 weeks after replate $2 . A$ (low power) and $B$ (high power) are photomicrographs of NT2-N cells produced using Hoffman modulation contrast optics. The labeled cells and processes appear dark gray or black because of the silver grains from the NTB-2 emulsion autoradiography. $A$ shows a field of cells containing labeled cell bodies and dendritic processes (arrowheads) with many unlabeled axonal processes (some examples are shown with arrows) arising from the clumps of cells in the field and elsewhere on the culture dish. $B$ shows a higher-power micrograph of several cells. The dendritic processes of one of these cells have been indicated using arrowheads. Scale bar: $100 \mu \mathrm{m}$ for $A ; 50 \mu \mathrm{m}$ for $B$.

cells on Matrigel began to elaborate their processes (Fig. 8C). These differential effects of Matrigel (or laminin) and poly-Dlysine on neurite regrowth in NT2-N cells are consistent with the well known neurite-outgrowth-promoting effects of laminin on a variety of PNS and CNS neuronal cells in culture (Manthorpe et al., 1983; Rogers et al., 1983). The ability of NT2-N cells to regenerate neurites after multiple replating shows that they retain the plasticity of immature neurons. Replate 3 affords us a means to obtain more pure cultures of NT2-N cells (at least $99 \%$ ), and we have shown that pure neurons can be frozen at this stage and reconstituted at a later date (data not shown). These factors will allow us to pursue experiments in the future that depend on the availability of purer cultures and facilitate study of many features of NT2-N cells in other laboratories.

In addition to the substratum, non-neuronal cells played a role in promoting neurite outgrowth; this is most evident in replate 3 cultures. We observed that NT2-N cells replated on poly-D-lysine alone were clustered around the extremely rare non-neuronal cells found in these cultures, and that many neurites from the clump of NT2-N cells extended directly toward the non-neuronal cells. A dramatic example of this phenomenon is shown in Figure $8 D$, in which several processes appear to have changed direction dramatically in order to grow toward the non-neuronal cell. Repeated observation of the cells in Fig-
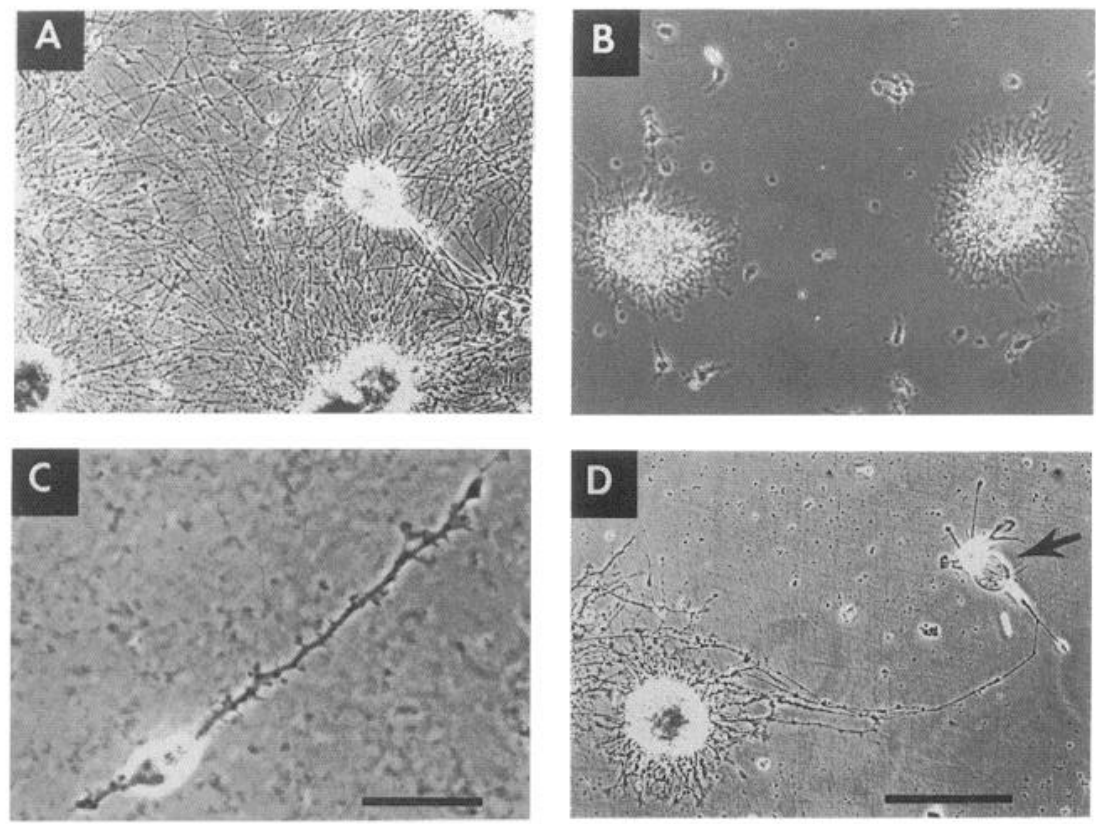

Figure 8. Neurite regeneration following replate $3 . A, \mathrm{NT} 2-\mathrm{N}$ cells grown on Matrigel for 1 week following replate 3. $B$, NT2-N cells grown on poly-D-lysine for 1 week following replate 3 . $C$, An NT2-N cell grown on Matrigel for $1 \mathrm{~d}$ following replate $3 . D$, NT2-N cells grown on poly-D-lysine for 1 week following replate 3 . The arrow in $D$ points to a flat non-neuronal cell. Scale bars: $D$ (for $A, B$, and $D$ ), $200 \mu \mathrm{m} ; C, 30 \mu \mathrm{m}$. 


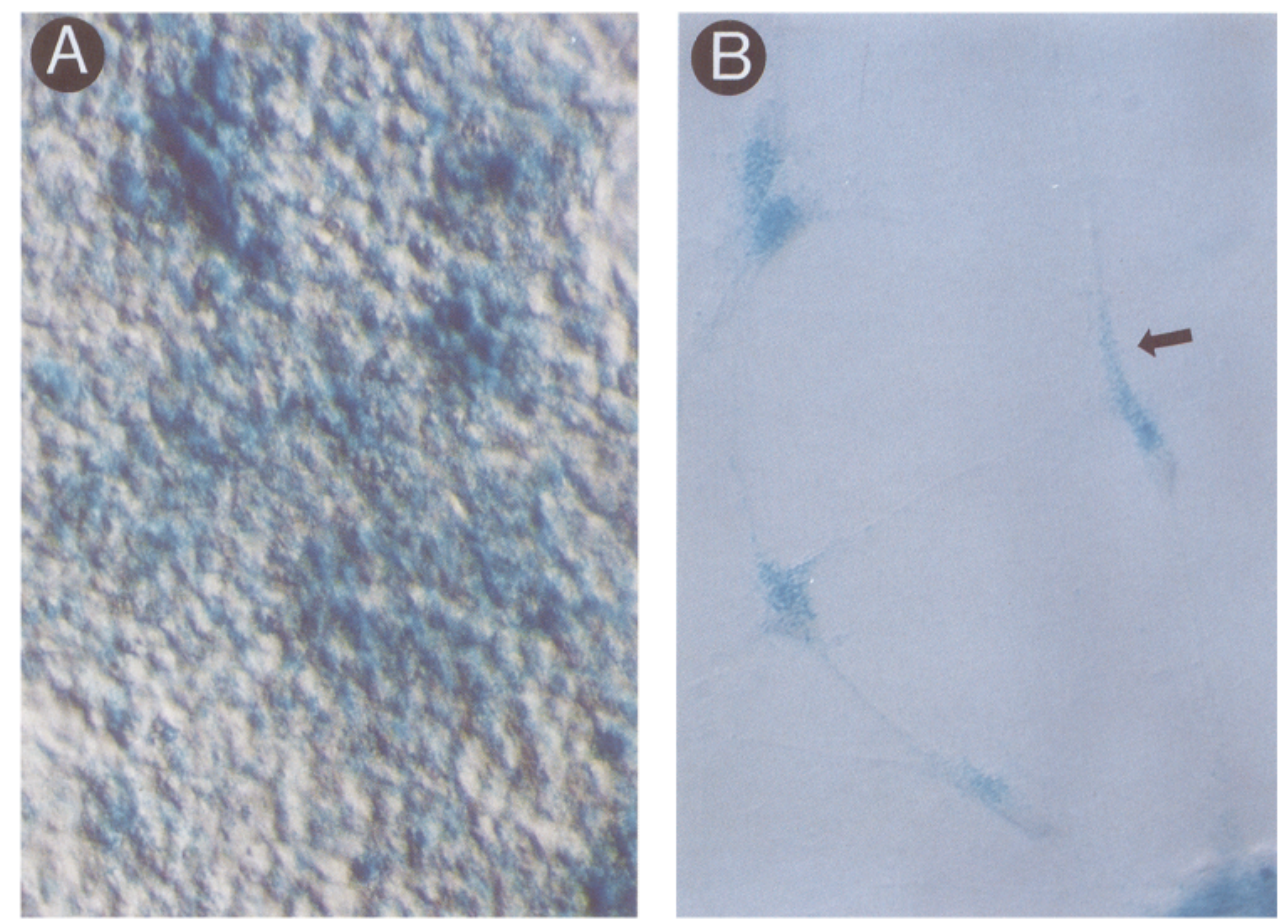

Figure 9. $\quad \beta-\mathrm{Gal}$ expression of NT2SPUD cells visualized by X-gal histochemistry using Hoffman modulation contrast microscopy. $A$, NT2-SPUD cells before RA treatment. $B$ and $C$ NT2-SPUD cells after replate 2 . Scale bars: $100 \mu \mathrm{m}$ for $A$ and $C ; 50 \mu \mathrm{m}$ for $B$

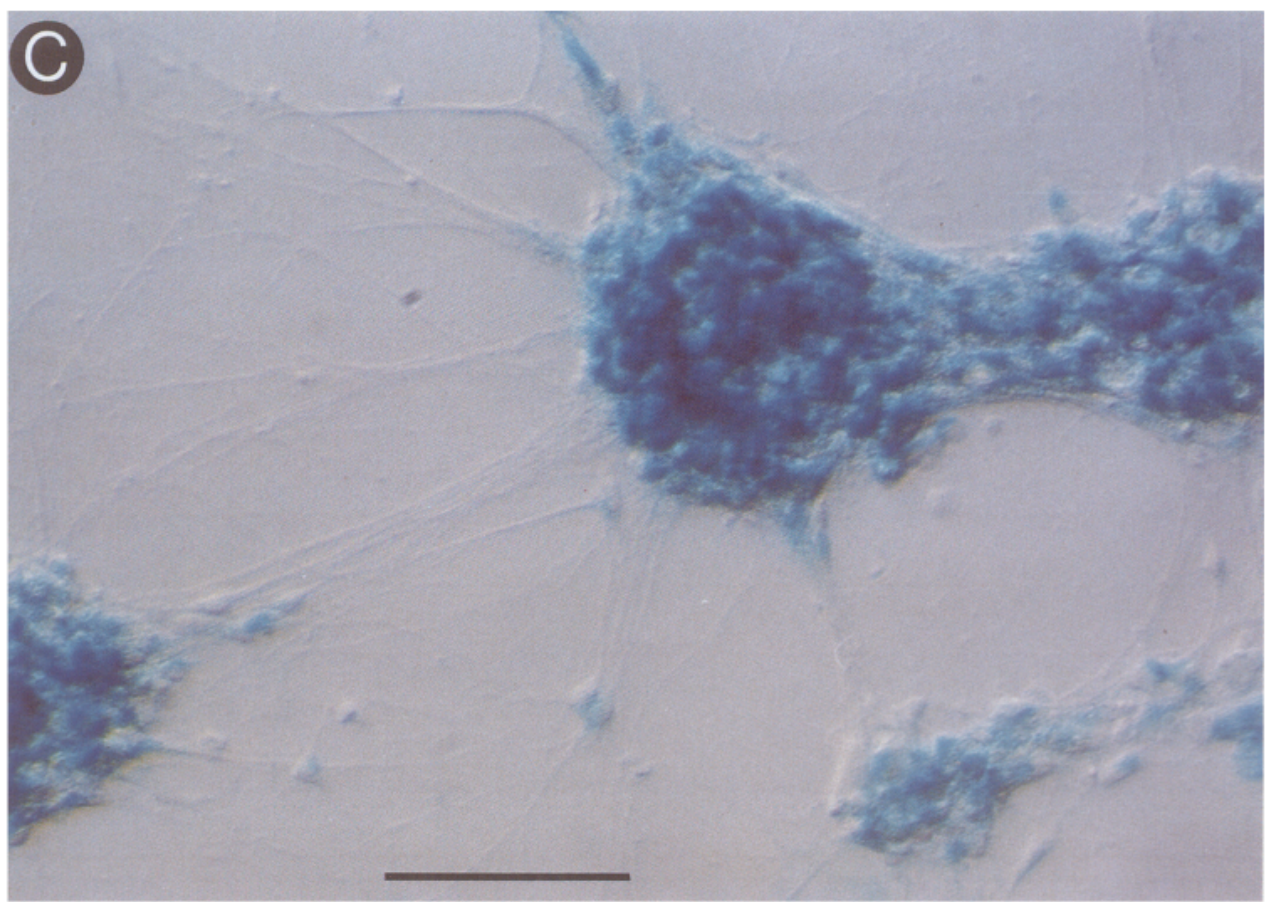

ure $8 D$ revealed that the neurites retracted completely following the death of the non-neuronal cell (data not shown). This result implies that residual non-neuronal cells may release a diffusible substance that is chemotropic for NT2-N cells. Similarly, the presence of non-neuronal cells may explain the extended viability of NT2-N on a non-neuronal cell monolayer (up to 7 months) compared to the pure NT2-N cell cultures (8-10 weeks). Taken together, these studies suggest a role for non-neuronal cells in promoting both the survival of NT2-N cells and neurite extension.
NT2 cells are transfectable and the proteins expressed continue to be present in NT2-N cells

To assess the utility of NT2-N cells for gene transfer experiments, we stably transfected undifferentiated NT2 cells with SPUD1, a $\beta$-gal expression plasmid. These studies were designed to determine whether NT2-N cells would continue to express the exogenous protein product following differentiation with RA. When SPUD1 was cotransfected with pSV2neo (used as a selectable marker) into undifferentiated NT2 cells, we derived 
a G418 resistant population of cells that expressed $\beta$-gal as assayed by histochemical staining (Fig. 9A). Upon stimulation of these NT2-SPUD cells with RA, following the same protocol as described in Figure 1, we were able to derive pure cultures of $\beta$-gal-positive NT2-N cells (Fig. 9B,C). The blue reaction product indicating the presence of $\beta$-gal protein was concentrated in the cell soma and only extended into the processes of some of the NT2-N cells (see arrow in Fig. 9B). The $\beta$-gal reaction product appeared to be concentrated in granular aggregates throughout the cell body (Fig. 9B). This finding suggests that NT2-N cells will continue to express exogenous gene products introduced into NT2 cells.

\section{General considerations}

Our observations here on the NT2-N cells and the novel methods developed for their culture show that it is possible to generate pure cultures of postmitotic, human neurons from rapidly dividing NT2 teratocarcinoma cells following RA treatment. These nondividing NT2-N cells have a stable neuronal phenotype, and they can survive in culture for up to 10 weeks without the continuous presence of any exogenous differentiation promoting or trophic factors other than those in serum. Indeed, using the method described here, we have consistently produced NT2-N cells at weekly intervals for over a year, and sufficient numbers of these cells were readily generated for biochemical experiments. It is also highly significant that the postmitotic, neuronlike NT2-N cells continue to express proteins encoded by plasmids transfected into the undifferentiated NT2 cells. This combination of features is unique since, for the first time, cultured human cells with a fully differentiated neuronal phenotype are available in large numbers for the study of basic questions in neurobiology including timed neurite outgrowth, the basis and development of neurite polarity, cytoskeletal maturation, and neuronal plasticity.

No pure cultures other than those obtained from primary cultures of neurons (and now NT2-N cells) have been shown to maintain a stable polarized phenotype. Thus, it is likely that neuritic polarity is a very highly differentiated feature of neurons and cannot be attained by neuronal cell lines while going through the cell cycle. Because of this limitation, studies on neuronal polarity can only be carried out using primary cultures of postmitotic neurons. Although much progress has been made in understanding certain aspects of neuronal polarity such as its timing (Dotti and Banker, 1987; Dotti et al., 1988; Goslin et al., 1988, 1990; Goslin and Banker, 1989, 1990), its dependence on extracellular matrix (Lein and Higgins, 1989; Lein et al., 1991), and the dependence of axonal growth on the presence of tau in cerebellar neurons (Caceres and Kosik, 1990; Caceres et al., 1991), many types of experiments that might shed light on the fundamental nature of polarity and its development have been difficult to perform given the technical limitations imposed by using primary cultures. Indeed, the ability to introduce foreign gene products into NT2 cells using standard gene transfer techniques and the ability to produce large numbers of pure polarized NT2-N cultures will allow studies involving the expression of mutant proteins that might disturb polarity and thus lead to an understanding of the processes that control this vital feature of neurons.

NT2-N cells expressed all of the key neuronal markers we examined. Further, they have specific characteristics that indicate that they are CNS (and not PNS) neurons [i.e., they express NF-66 and do not express peripherin (Table 1) or a newly described high molecular weight $(110 \mathrm{kDa})$ form of tau found only in the PNS (Fig. 5; Goedert, personal communication)]. Like many primary neurons in culture, NT2-N cells have a cytoskeleton dominated by the immature forms of MAPs and NF proteins (e.g., they express primarily fetal tau, MAP 1B, MAP2B), but they do synthesize and maintain lower quantities of MAP 1A and NF-H (data not shown). Given the stable neuronal phenotype assumed by NT2-N cells and the fact that they can be genetically engineered to express the products of transfected genes, these cells will be extremely useful for examining the cell biology and the functions of neuronal proteins in human neurons. The prompt neurite regeneration following replating (see Fig. 8) and the expression of well-characterized cell adhesion molecules (see Table 1) will allow NT2-N cells to be utilized for studying factors that regulate neurite outgrowth. Since NT2-N cells do not divide even in the presence of serum and they represent a reproducible source of highly purified human neuronal cultures, they may be useful cells for transplantation studies into nude mice and other mammals to determine their ability to integrate into the host environment. Indeed, the transfection of trophic factors or other proteins into NT2 cells that are then induced to differentiate into stable, postmitotic neurons may be useful as a novel delivery system for bioactive molecules in human neurodegenerative diseases.

\section{References}

Andrews PW (1984) Retinoic acid induces neuronal differentiation of a cloned human embryonal carcinoma cell line in vitro. Dev Biol 103 285-293.

Andrews PW, Damjanov I, Simon D, Banting GS, Carlin C, Dracopoli NC, Fogh J (1984) Pluripotent embryonal carcinoma clones derived from the human teratocarcinoma cell line Tera-2. Lab Invest 50:147162.

Baas PW, Deitch JS, Black MM, Banker GA (1988) Polarity orientation of microtubules in hippocampal neurons: uniformity in the axon and nonuniformity in the dendrite. Proc Natl Acad Sci USA 85:8335-8339.

Baas PW, Black MM, Banker GA (1989) Changes in microtubule polarity orientation during the development of hippocampal neurons in culture. J Cell Biol 109:3085-3094.

Banker GA, Cowan WM (1979) Further observations on hippocampal neurons in dispersed cell culture. J Comp Neurol 187:469-494.

Bartlett PF, Reid HH, Bailey KA, Bernard O (1988) Immortalization of mouse neural precursor cells by the c-myc oncogene. Proc Natl Acad Sci USA 85:3255-3259.

Benowitz LI, Routtenberg A (1987) A membrane phosphoprotein associated with neural development, axonal regeneration, phospholipid metabolism, and synaptic plasticity. Trends Neurosci 10:527532.

Birren SJ, Anderson DJ (1990) A v-myc-immortalized sympathoadrenal progenitor cell line in which neuronal differentiation is initiated by FGF but not NGF. Neuron 4:189-201.

Black MM, Baas PW (1989) The basis of polarity in neurons. Trends Neurosci 12:211-214.

Brody BA, Ley CA, Parysek LM (1989) Selective distribution of the $57 \mathrm{kDa}$ neural intermediate filament protein in the rat CNS. J Neurosci 9:2391-2401.

Burton PR, Paige JL (1981) Polarity of axoplasmic microtubules in the olfactory nerve of the frog. Proc Natl Acad Sci USA 78:32693273.

Caceres A, Kosik KS (1990) Inhibition of neurite polarity by tau antisense oligonucleotides in primary cerebellar neurons. Nature 343: $461-463$.

Caceres A, Banker G, Steward O, Binder L, Payne M (1984) MAP2 is localized to the dendrites of hippocampal neurons which develop in culture. Dev Brain Res 13:314-318.

Caceres A, Potrebic S, Kosik KS (1991) The effect of tau antisense oligonucleotides on neurite formation of cultures of cerebellar macroneurons. J Neurosci 11:1515-1523. 
Calvert R, Anderton BH (1985) A microtubule-associated protein (MAPl) which is expressed at elevated lcvels during development of the rat cerebellum. EMBO J 4:1171-1176.

Carden MJ, Trojanowski JQ, Schlaepfer WW, Lee VM-Y (1987) Twostage expression of neurofilament polypeptides during rat neurogenesis with early establishment of adult phosphorylation patterns. J Neurosci 7:3489-3504.

Cepko CL (1989) Immortalization of neural cells via retrovirus-mediated oncogene transduction. Annu Rev Neurosci 12:47-65.

Chiu F-C, Barnes EA, Das K, Haley J, Socolow P, Macaluso FP, Fant J (1989) Characterization of a novel $66 \mathrm{kd}$ subunit of mammalian neurofilaments. Neuron 2:1435-1445.

Darmon M, Buc-Caron M-H, Paulin D, Jacob F (1982) Control by the extracellular environment of differentiation pathways in 1003 embryonal carcinoma cells: study at the level of specific intermediate filaments. EMBO J 1:901-906.

Davis L, Banker GA, Steward O (1987) Selective dendritic transport of RNA in hippocampal neurons in culture. Nature 330:477-479.

Davis L, Burger B, Banker GA, Steward O (1990) Dendritic transport: quantitative analysis of the time course of somatodendritic transport of recently synthesized RNA. J Neurosci 10:3056-3068.

Dotti CG, Banker GA (1987) Experimentally induced alteration in polarity of developing neurons. Nature 330:254-256.

Dotti CG, Banker GA, Binder LI (1987) The expression and distribution of the microtubule-associated proteins tau and microtubuleassociated protein 2 in hippocampal neurons in the rat in situ and in cell culture. Neuroscience 23:121-130.

Dotti CG, Sullivan CA, Banker GA (1988) The establishment of polarity by hippocampal neurons in culture. J Neurosci 8:1454-1468.

Dubois C, Manuguerra J-C, Hauttecoeeur B, Maze J (1990) Monoclonal antibody A2B5, which detects cell surface antigens, binds to ganglioside $\mathrm{G}_{\mathrm{T} 3}\left(\mathrm{II}^{3}(\mathrm{NeuAc})_{3} \mathrm{LacCer}\right)$ and to its 9-O-acetylated derivative. J Biol Chem 265:2797-2803.

Escurat M, Djabali K, Gumpel M, Gros F, Portier M-M (1990) Differential expression of two neuronal intermediate-filament proteins, peripherin and the low-molecular-mass neurofilament protein (NFL), during the development of the rat. J Neurosci 10:764-784.

Foster GA, Dahl D, Lee VM-Y (1987) Temporal and topographic relationships between the phosphorylated and nonphosphorylated epitopes of the $200 \mathrm{kDa}$ neurofilament protein during development in vitro. J Neurosci 7:2651-2663.

Francon J, Lennon AM, Fellous A, Mareck A, Pierre M, Nunez J (1982) Heterogeneity of microtubule-associated proteins and brain development. Eur J Biochem 129:465-471.

Fredericksen K, Jat PS, Valtz N, Levy D, McKay R (1988) Immortalization of precursor cells from the mammalian CNS. Neuron 1: 439-448.

Garner CC, Garner A, Huber G, Kozak C, Matus A (1990) Molecular cloning of microtubule-associated protein 1 (MAP1A) and microtubule-associated protein 5 (MAP1B): identification of distinct genes and their differential expression in developing brain. $J$ Neurochem 55:146-154.

Geisert EE, Johnson HG, Binder LI (1990) Expression of microtubuleassociated protein 2 by reactive astrocytes. Proc Natl Acad Sci USA 87:3967-3971.

Georgieff IS, Liem RKH, Mellado W, Nunez J, Shelanski ML (1991) High molecular weight tau: preferential localization in the peripheral nervous system. J Cell Sci 100:55-60.

Gorham JD, Baker H, Kegler D, Ziff EB (1990) The expression of the neuronal intermediate filament protein peripherin in the rat embryo. Dev Brain Res 57:235-248.

Goslin K, Banker G (1989) Experimental observations on the development of polarity by hippocampal neurons in culture. J Cell Biol 108:1507-1516.

Goslin K, Banker G (1990) Rapid changes in the distribution of GAP43 correlate with the expression of neuronal polarity during normal development and under experimental conditions. J Cell Biol 110: 1319-1331.

Goslin K, Schreyer DJ, Skene JHP, Banker G (1988) Development of neuronal polarity: GAP-43 distinguishes axonal from dendritic growth cones. Nature 336:672-674.

Goslin K, Schreyer DJ, Skene JHP, Banker G (1990) Changes in the distribution of GAP-43 during the development of neuronal polarity. J Neurosci 10:588-602

Greene LA, Tischler AS (1982) $\mathrm{PCl} 2$ pheochromocytoma cultures in neurobiological research. In: Advances in cellular neurobiology (Federoff S, IIertz L, eds), pp 373-414. New York: Academic.

Hammang JP, Baetge EE, Behringer RR, Brinster RL, Palmiter RD, Messing A (1990) Immortalized retinal neurons from SV40 T-antigen-induced tumors in transgenic mice. Neuron 4:775-782.

He X, Skapek SX, Wikstrand CJ, Friedman HS, Trojanowski JQ, Kemshead JT, Coakham HB, Bigner SH, Bigner DD (1989) Phenotypic analysis of four human medulloblastoma cell lines and transplantable xenografts. J Neuropathol Exp Neurol 48:48-68.

Heidemann SR, Landers JM, Hamborg MA (1981) Polarity orientation of axonal microtubules. J Cell Biol 91:661-665.

Huber G, Matus A (1984) Differences in the cellular localization of two microtubule associated proteins, MAP 1 and MAP 2, in the rat brain. J Neurosci 4:151-160.

Johnson JE, Birren SJ, Anderson DJ (1990) Two rat homologues of Drosophila achaete-scute specifically expressed in neuronal precursors. Nature 346:858-861.

Jones-Villeneuve EMV, McBurney MW, Rogers KA, Kalnins VI (1982) Retinoic acid induces embryonal carcinoma cells to differentiate into neurons and glial cells. J Cell Biol 94:253-262.

Julien J-P, Meyer D, Flavell D, Hurst J, Grosveld F (1986) Cloning and developmental expression of the murine neurofilament gene family. Mol Brain Res 1:243-250.

Kaplan MP, Chin SSM, Fliegner KH, Liem RKH (1990) $\alpha$-Internexin, a novel neuronal intermediate filament protein, precedes the low molecular weight neurofilament protein (NF-L) in the developing rat brain. J Neurosci 10:2735-2748.

Kleinman HK, McGarvey ML, Hassell JR, Star VL, Cannon FB, Laurie GW, Martin GR (1986) Basement membrane complexes with biological activity. Biochemistry 25:312-318.

Kosik KS, Finch EA (1987) MAP2 and tau segregate into dendritic and axonal domains after the elaboration of morphologically distinct neurites: an immunocytochemical study of cultured rat cerebrum. J Neurosci 7:3142-3153.

Kuff EL, Fewell JW (1980) Induction of neural-like cells and acetylcholinesterase activity in cultures of F9 teratocarcinoma treated with retinoic acid and dibutyryl cyclic adenosine monophosphate. Dev Biol 77:103-115.

Lang E, Mazauric-Stucker M-L, Maelicke A (1989) States of developmental commitment of a mouse embryonal carcinoma cell line differentiating along a neural pathway. J Cell Biol 109:2481-2493.

Lee G, Cowan N, Kirschner M (1988) The primary structure and heterogeneity of tau protein from mouse brain. Science 239:285-288.

Lee V, Greene LA, Shelanski ML (1981) Identification of neural and adrenal medullary surface membrane glycoproteins recognized by antisera to cultured rat sympathetic neurons and PC12 pheochromocytoma cells. Neuroscience 6:2773-2786.

Lee VM-Y, Andrews PW (1986) Differentiation of NTERA-2 clonal human embryonal carcinoma cells into neurons involves the induction of all three neurofilament proteins. J Neurosci 6:514-521.

Lee VM-Y, Page CD, Wu HL, Schlaepfer WW (1984) Monoclonal antibodies to gel-excised glial filament protein and their reactivities with other intermediate filament proteins. J Neurochem 42:25-32.

Lee VM-Y, Carden MJ, Schlaepfer WW, Trojanowski JQ (1987) Monoclonal antibodies distinguish several differentially phoshorylated states of the two largest rat neurofilament subunits (NF-H and NF-M) and demonstrated their existence in the normal nervous system of adult rats. J Neurosci 7:3474-3488.

Lein PJ, Higgins D (1989) Laminin and a basement membrane extract have different effects on axonal and dendritic outgrowth from embryonic rat sympathetic neurons in vitro. Dev Biol 136:330-345.

Lein PJ, Higgins D, Turner DC, Flier LA, Terranova VP (1991) The $\mathrm{NCl}$ domain of Type IV collagen promotes axonal growth in sympathetic neurons through interaction with the $\alpha_{1} \beta_{1}$ integrin. J Cell Biol 113:417-428.

Lendahl U, McKay RDG (1990) The use of cell lines in neurobiology. Trends Neurosci 13:132-137.

I endahl U, Zimmerman LB, McKay RDG (1990) CNS stem cells express a new class of intermediate filament protein. Cell 60:585595.

Lo L-C, Birren SJ, Anderson DJ (1991) v-myc immorlalization of early rat neural crest cells yields a clonal cell line which generates both glial and adrenergic progenitor cells. Dev Biol 145:139-153.

Manthorpe M, Engvall E, Ruoslahti E, Longo FM, Davis GE, Varon S 
(1983) Laminin promotes neuritic regeneration from cultured peripheral and central neurons. J Cell Biol 97:1882-1890.

Mareck A, Fellous A, Francon J, Nunez J (1980) Changes in composition and activity of microtubule-associated proteins during brain development. Nature 284:353-355.

Matus A (1988) Microtubule-associated proteins: their potential role in determining neuronal morphology. Annu Rev Neurosci 11:29-44.

Matus A, Bernhardt R, Hugh-Jones T (1981) High molecular weight microtubule-associated proteins are preferentially associated with dendritic microtubules in brain. Proc Natl Acad Sci USA 78:30103014.

Parysek LM, Goldman RD (1988) Distribution of a novel $57 \mathrm{kDa}$ intermediate filament (IF) protein in the nervous system. J Neurosci 8:555-563.

Patel K, Bourne S, Coakham H, Kemshead JT (1990) Expression of the neural cell adhesion molecule in human brain tumours. Biochem Soc Trans 18:264.

Paulin D, Jakob H, Jacob F, Weber K, Osborn $M$ (1982) In vitro differentiation of mouse teratocarcinoma cells monitored by intermediate filament expression. Differentiation 22:90-99.

Peng I, Binder LI, Black MM (1986) Biochemical and immunological analyses of cytoskeletal domains of neurons. J Cell Biol 102:252-262.

Pfeiffer SE, Jakob H, Mikoshiba K, Bubois P, Guenet JL, Nicolas J-F, Gaillard J, Chevance G, Jacob F (1981) Differentiation of a teratocarcinoma line: preferential development of cholinergic neurons. J Cell Biol 88:57-66.

Pleasure SJ, Lec VM-Y, Nelson DL (1990) Sitc-specific phosphorylation of the middle molecular weight human neurofilament protein in transfected non-neuronal cells. J Neurosci 10:2428-2437.

Rendt J, Erulkar S, Andrews P (1989) Presumptive neurons derived by differentiation of a human embryonal carcinoma cell line exhibit tetrodotoxin-sensitive sodium currents and the capacity for regenerative responses. Exp Cell Res 180:580-584.

Riederer B, Matus A (1985) Differential expression of distinct microtubule-associated proteins during brain development. Proc Natl Acad Sci USA 82:6006-6009.

Riederer B, Cohen R, Matus A (1986) MAP5: a novel brain microtubule-associated protein under strong developmental regulation. $\mathbf{J}$ Neurocytol 15:763-775.

Rogers SL, Letourneau PC, Palm SL, McCarthy J, Furcht LT (1983) Neurite extension by peripheral and central nervous system neurons in response to substratum-bound fibronectin and laminin. Dev Biol 98:212-220.
Ronnett GV, Hester LD, Nye JS, Connors K, Snyder SH (1990) Human cortical neuronal cell line: establishment from a patient with unilateral megalencephaly. Science 248:603-605.

Ryder EF, Snyder EY, Cepko CK (1990) Establishment and characterization of multipotent neural cell lines using retrovirus vectormediated oncogene transfer. J Neurobiol 21:356-375.

Sargent PB (1989) What distinguishes axons from dendrites? Neurons know more than we do. Trends Neurosci 12:203-205.

Schoenfeld TA, McKerracher L, Obar R, Vallee RB (1989) MAP1A and MAP1B are structurally related microtubule associated proteins with distinct developmental patterns in the CNS. J Neurosci 9:17121730

Steward O, Levy WB (1982) Preferential localization of polyribosomes under the base of dendritic spines in granule cells of the dentate gyrus. J Neurosci 2:284-291.

Temple S (1990) Characteristics of cells that give rise to the central nervous system. J Cell Sci 97:213-218.

Theodosis DT, Rougon G, Poulain DA (1991) Retention of embryonic features by an adult neuronal system capable of plasticity: polysialated neural cell adhesion molecule in the hypothalamo-neurohypophysial system. Proc Natl Acad Sci USA 88:5494-5498.

Tohyama T, Lee VM-Y, Rorke LB, Trojanowski JQ (1991) Molecular milestones that signal axonal maturation and the commitment of human spinal cord precursor cells to the neuronal or glial phenotype in development. J Comp Neurol 310:285-299.

Trojanowski JQ, Kelsten ML, Lee Vm-Y (1989a) Phosphate-dependent and independent neurofilament protein epitopes are expressed throughout the cell cycle in human medulloblastoma (D283 MED) cells. Am J Pathol 135:747-758.

Trojanowski JQ, Schuck T, Schmidt ML, Lee VM-Y (1989b) Distribution of tau proteins in the normal human central and peripheral nervous system. J Histochem Cytochem 37:209-215.

Tucker RP, Garner CC, Matus A (1989) In situ localization of microtubule-associated protein mRNA in the developing and adult rat brain. Neuron 2:1245-1256.

Walsh C, Cepko CL (1988) Clonally related cortical cells show several migration patterns. Science 241:1342-1345.

Wiedenmann B, Huttner WB (1989) Synáptophysin and chromagranins/secretogranins - widespread constituents of distinct types of neuroendocrine vesicles and new tools in tumor diagnosis. Virchows Arch [Ccll Pathol] 58:95-121. 